\title{
By-catch and monetary loss of pufferfish in Turkey, the Eastern Mediterranean
}

\section{Doğu Akdeniz, Türkiye'de balon balıklarının hedef dışı avı ve parasal zararları}

\author{
Fikret Öndes $^{{ }^{*}} \bullet$ Vahdet Ünal $^{2} \bullet$ Yeliz Özbilgin ${ }^{3} \bullet$ Cengiz Deval ${ }^{4} \bullet$ Cemal Turan ${ }^{5}$ \\ 'Faculty of Fisheries, İzmir Kâtip Çelebi University, İzmir, 35620, Turkey (D) https://orcid.org/0000-0002-9522-7050 \\ ${ }^{2}$ Faculty of Fisheries, Ege University, İzmir, 35100, Turkey (iD https://orcid.org/0000-0001-6157-0590 \\ ${ }^{3}$ Faculty of Fisheries, Mersin University, Mersin, 33160, Turkey (iD) https://orcid.org/0000-0002-1074-4287 \\ ${ }^{4}$ Faculty of Fisheries, Akdeniz University, Antalya, 07058, Turkey (D) https://orcid.org/0000-0001-9854-0037 \\ ${ }^{5}$ Marine Sciences and Technology Faculty, İskenderun Technical University, İskenderun, 31200, Turkey iD https://orcid.org/0000-0001-9584-0261 \\ *Corresponding author:fikret.ondes@ikc.edu.tr
}

How to cite this paper:

Öndes F., Ünal V., Özbilgin Y., Deval C. \& Turan, C. (2018). By-catch and monetary loss of pufferfish in Turkey, the Eastern Mediterranean. Ege Journal of Fisheries and Aquatic Sciences, 35(4), 361-372. DOI: 10.12714/egejfas.2018.35.4.01

\begin{abstract}
Non-native pufferfish have been a part of the Mediterranean marine ecosystem since the 1930s. However, there is a lack of knowledge regarding the by-catch of these species. This study aimed to compare the by-catch of pufferfish species between different types of fishing gear and to determine the monetary losses due to pufferfish on the Aegean (west) and Mediterranean (south) coasts of Turkey. A total of 467 commercial and recreational fishers ( $n=244$ and $n=223$ respectively), based in the 7 coastal cities were interviewed in the period of June - December 2017. A semi-structured questionnaire provided detailed information on by-catch amount of pufferfish in fishing gears, and economic loss caused by pufferfish. The most commonly caught pufferfish species was Lagocephalus sceleratus. The by-catch amount of pufferfish is higher on the Mediterranean coast in comparison with the Aegean coast. The highest pufferfish by-catch was recorded in purse seines and trawls on the south coasts, but in set nets on the west coasts. When seasonal changes were considered, the highest by-catch was occurred in the summer months for both commercial and recreational fisheries. Regarding the damages caused by pufferfish species in the small-scale fisheries, $92 \%$ and $90 \%$ of fishers, who fished on the south coasts, claimed that pufferfish species damage their fishing gears and fish entangled to these fishing gears, respectively. In conclusion, pufferfish species (e.g. L. sceleratus) are part of the ecosystem with their unknown quantified impacts. In fact, such information is required for fisheries management to mitigate the impacts of these species. The present study contributes to filling the gaps in this area.

Keywords: Pufferfish, Lagocephalus sceleratus, by-catch, local ecological knowledge, monetary loss, Mediterranean Sea

Öz: Yerli olmayan balon balıkları 1930'lu yıllardan beri Akdeniz ekosisteminin bir parçası olmasına rağmen bu türlerin hedef dışı avı konusu ile ilgili bilgi eksikliği söz konusudur. Bu çalısma, Türkiyénin Ege ve Akdeniz kıyllarında balon balıklarııı farklı av araçlarındaki hedef dıșı avını kıyaslamayı ve balon balıklarından kaynaklanan parasal zararları tespit etmeyi amaçlamıştır. Calıșma kapsamında, Haziran-Aralık 2017 periyodunda 7 kıyı ilinde, toplam 467 ticari ve amatör balıkçı ( $n=244$ ve $n=223$ sırasıyla) ile görüșülmüşsür. Yarı yapılandııılmış anket, balon balıklarııın av araçlarındaki hedef dışı av miktarı ve balıkçılıkta sebep oldukları parasal zararlar hakkında detaylı bilgi sağlamıştı. Av araçclarında yakalanan en yaygın balon balı̆ı ıürü Lagocephalus sceleratus olarak tespit edilmiştir. Akdeniz kııııındaki hedef dışı av miktarı Ege kııııına nazaran daha yüksek bulunmuştur. En yüksek hedef dışı av miktarı, güney kıyılarında gırgır ve trollerden kaydedilirken, batı kıyllarında uzatma ağlarında tespit edilmiştir. Mevsimsel değişimler dikkate alındığında, hem ticari hem de amatör balıkçlıkta en yüksek hedef dışı av yaz aylarında gözlemlenmiş̧ir. Güney kıyllarında avlanan küçük ölçekli balıkçıların \% 92'si balon balıklarııın av araçlarında hasara sebep olduğunu belirtmiş ve ayrıca balıkçların \%90', bu türlerin yakaladılkları hedef ava da zarar verdiklerini rapor etmişlerdir. Sonuç olarak, balon balı̆ı türleri (örn. L. sceleratus), bilinmeyen etkileri ile ekosistemin bir parçasılıı. Bu tưrlerin etkilerini azaltmak için balıkçıllk yönetiminde bazı bilgilere ihtiyaç duyulmaktadır. Mevcut çalıșma, bu alandaki boșlukları doldurmaya katkı koymaktadır.
\end{abstract}

Anahtar kelimeler: Balon balıkları, Lagocephalus sceleratus, hedef dıș av, lokal ekolojik bilgi, parasal zarar, Akdeniz 


\section{INTRODUCTION}

Since the opening of the Suez Canal in 1869, the ecosystem of Mediterranean Sea has been exposed to non-indigenous species (NIS) which are called "Lessepsian" and the rates of immigrations of fish species have increased over several decades (Por, 1964; Kalogirou, 2013). Lessepsian species exhibit both ecological and socio-economic impacts (Kosker et al., 2016). More specifically, some species cause problems for both commercial and recreational fishers; damage through to fishing gears and the target catch (Katikou et al., 2009; Nader et al., 2012; Ünal et al., 2015). Moreover, these species reduce the local stocks of commercial species through the predation (Kalogirou, 2013). Some Lessepsians, such as pufferfish are also dangerous for human and animal consumption (Chamandi et al., 2009; Beköz et al., 2013).

Tetrodontidae family members are commonly known as pufferfish, balloon fish, toad fish or globe fish and the aforementioned family includes 190 species worldwide (Hastings et al., 2014). To date, although Bilecenoğlu et al. (2014) reported a total of 7 pufferfish species in Turkish waters, according to Turan et al. (2017) 8 pufferfish species have been recorded. This difference is related to the identification of $L$. spadiceus and $L$. guentheri. Vella et al. (2017) suggested that $L$. spadiceus and $L$. guentheri may be the same species and more research needed for the correct taxonomic identification. Table 1 shows the list of pufferfish species have been recorded in Turkish waters, along with details of initial confirmed record data and location where available. The pufferfish, Lagocephalus sceleratus was first recorded in Turkish waters in February 2003 in Gökova Bay (Akyol et al., 2005) and was listed within the 100 Invasive Alien Species (IAS) in the Mediterranean Sea because of the presence of tetrodotoxin, a source of food poisoning (Streftaris and Zenetos, 2006; Kalogirou, 2013).

Table 1. Pufferfish species that were first reported in Turkish waters

\begin{tabular}{clllll}
\hline & & \multicolumn{2}{c}{ Initial Record } & \\
Species name & Year & Location & References \\
\hline$\checkmark$ & Lagocephalus guentheri (Miranda Ribeiro, 1915) & 1949 & İskenderun & Kosswig, 1950 \\
$\checkmark$ & Lagocephalus lagocephalus (Linnaeus, 1758) & NA & NA & Aksiray, 1987 \\
$\checkmark$ & Lagocephalus suezensis (Clark and Gohar, 1953) & 1998 & Mersin & Avşar and Çiçek, 1999 \\
$\checkmark$ & Sphoeroides pachygaster (Müller and Troschel, 1848) & 1999 & Saros & Eryılmaz et al., 2003 \\
$\checkmark$ & Torquigener flavimaculosus (Hardy and Randall, 1983) & 2002 & Fethiye & Bilecenoğlu, 2005 \\
$\checkmark$ & Lagocephalus sceleratus (Gmelin, 1789) & 2003 & Gökova & Akyol et al., 2005 \\
$\checkmark$ & Tylerius spinosissimus (Regan, 1908) & 2010 & İskenderun & Turan and Yağlığlu, 2011 \\
\hline
\end{tabular}

By-catch can be defined as the incidental capture of non-target individuals in fishing gear and it consists of under sized individuals of the target species and all size classes of non-target species that have no commercial value (Kelleher, 2005; Soykan et al., 2008; Kaiser et al., 2011; Öndes et al., 2017a). By-catch can decrease the overall catch of target species and cause damage to fishing gear and the target catch (Kalogirou, 2013; Briceno et al., 2015). Little is documented about the bycatch of Lessepsian species, such as pufferfish (Yemişken et al., 2014; Çiçek and Avşar, 2015; Bilecenoğlu, 2016). The importance of monitoring by-catch species has increased based on the implementation of the Common Fishery Policy (CFP) of the European Commission (EP, 2015). To date, assessment of by-catch has been based on several data sources; fishery dependent data (FDD) (government statistics and logbooks etc.), fishery independent data (FID) (observer data), local ecological knowledge (LEK) and traditional ecological knowledge (TEK).

The LEK is a useful data source to understand the population ecology of species and to estimate the impact of human activities on ecosystems (Posey and Balick, 2006; Macdonald et al., 2014). In addition the catch characteristics of fish and invertebrates, bycatch issues are evaluated based on the LEK (Leite and Gasalla, 2013; Dawe and Schneider, 2014; Öndes et al., $2017 \mathrm{a}, \mathrm{b})$. The aforementioned data source has some advantages in comparison with the FID and FDD. For instance, fishery independent surveys are expensive sampling methods, while LEK is an inexpensive data source and it provides reliable data for the large localities via short terms surveys. It should be noted that LEK is also an important source of information on the distribution and abundance of Lessepsian species overtime (Azzurro et al., 2011; Deidun et al., 2015). Additionally, the data related to the economic losses to fisheries as a result of Lessepsian species is generally estimated using the questionnaire studies (Ünal et al., 2015; Ünal and Göncüoğlu-Bodur, 2017).

Previous studies on pufferfish in Turkish waters were related to the original confirmed records, 
distribution (Akyol and Ünal, 2017), toxicity (Acar et al., 2017) reproductive biology (Aydın, 2011; Çek-Yalnız et al., 2017) and feeding ecology (Aydın, 2011; Irmak, 2012). However, the economic impacts of pufferfish on the fisheries have been little studied to date (Ünal et al., 2015; Ünal and Göncüoğlu-Bodur, 2017). There has been no comprehensive study on by-catch issues of this group in Turkey. Consequently, the first objective of the present study was to compare the estimated bycatch amounts of pufferfish in different fishing gears. We also aimed to evaluate ecological knowledge on body size, seasonal and spatial by-catch estimations of pufferfish species as the second objective of the study. The last but not the least objective was to see the trend of the monetary losses caused by pufferfish for fishers compare to the previous values in the same area.

\section{MATERIALS AND METHODS}

A total of 244 commercial and 223 recreational fishers, in the seven coastal cities along the Aegean and Mediterranean coastlines of Turkey (Figure 1), were interviewed in the period of June to December 2017.

We had the interviews with the recreational anglers and commercial fishers included longliners, set netters, purse seiners and trawlers. Small scale fisheries were generally performed in shallow waters with boats smaller than $12 \mathrm{~m}$ in length with the main target species generally are the sparids, red mullets and octopus, which are also diets of pufferfish (Irmak, 2012; Kalogirou, 2013). Large scale fisheries included purse seiners and trawlers that generally target sardine and anchovy or shrimps and red mullets respectively.

A semi-structured questionnaire provided information on the bio-ecological characteristics, by-catch amounts and socio-economic impacts of pufferfish species in recreational, small scale and largescale fisheries in different locations. The survey was conducted in four parts.

The first part gathered the data related to the general characteristics of fishing (the annual days at sea, number of hooks for each operation of longlines, used daily net length for set nets, the averaged operation time for trawls and purse seines).

The second part was related to the local ecological knowledge. In this part, we asked questions to fishers for the identification of pufferfish species (questionnaires included the photos of pufferfish species which distributed Turkish waters and aforementioned photos were shown to fishers for identification). It was aimed to assess information on the comparison of fishing gears (fishing rod, set net, longline, purse seine, and trawl) in terms of estimated by-catch amounts of pufferfish species. In order to understand estimated by-catch amounts in different fishing gears, we asked this question; how many pufferfish did you catch in 2016? Moreover, the seasonal and spatial trends on pufferfish by-catch amounts were investigated. In order to understand the seasonal differences related to pufferfish by-catch, we asked followed question to small scale fishers (longliners and set netter) and recreational fishers, who fish all months during the year, which season have you encountered with the highest pufferfish by-catch? Regarding the spatial differences in the pufferfish by-catch, we compared two sub-area (Mediterranean Sea (south coast) including Hatay, Adana, Mersin and Antalya, and Aegean Sea (west coast) including İzmir, Aydın and Muğla. Other questions were aimed to assess information on;

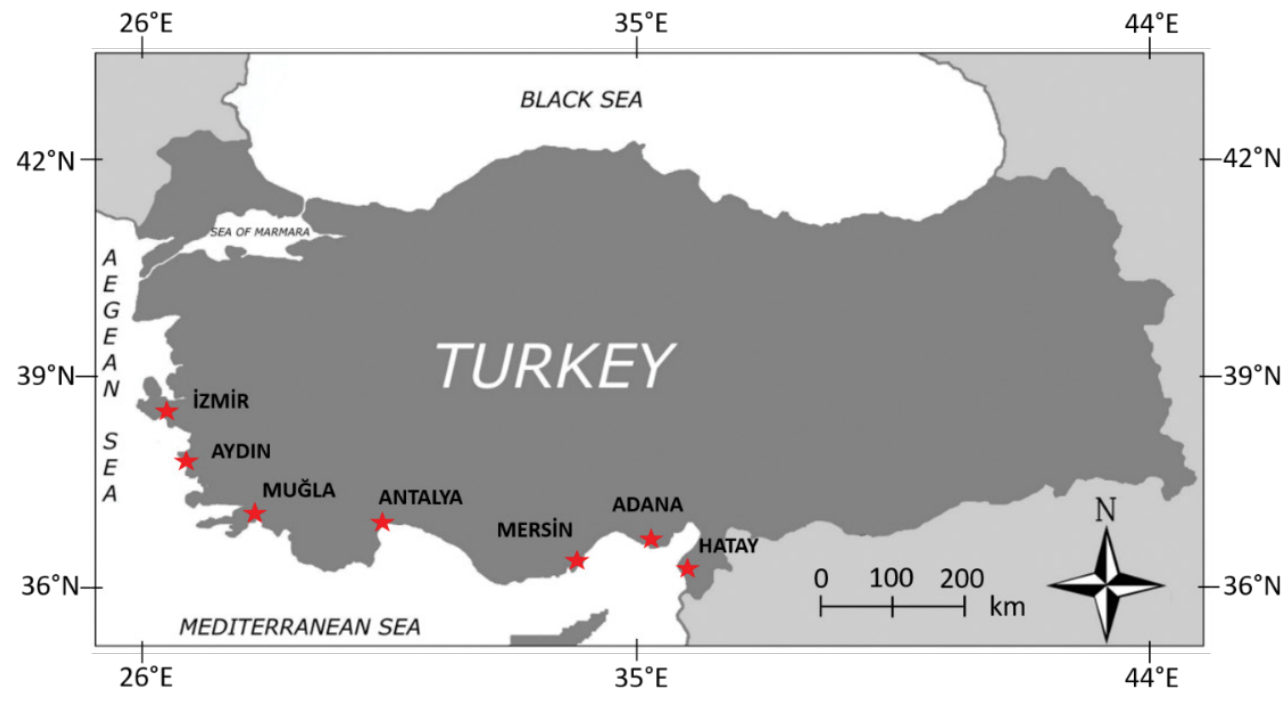

Figure 1. Map of the sampling areas (İzmir, Aydın, Muğla, Antalya, Mersin, Adana, and Hatay) 
a) the mean body length ( \pm SD) of caught pufferfish in different fishing gears,

b) their habitats in terms of depth and substrates.

Third part of the questionnaire dealt with the awareness of the fishers regarding the poisonous status of pufferfish. We aimed to understand whether fishers consume them or not. Other question was aimed to understand what fishers do in case of the caught of pufferfish.

The last part of the survey was evaluating the economic loss related to damaging fishing gears and target catch were estimated based on respondents' declarations to the relevant questions. Similarly, spatial differences related to the economic loss were investigated. It was also aimed to understand whether fishers fish the pufferfish as a target species in the future. We asked the following questions; Can you catch pufferfish, if you would have been paid 5 TL (1TL = 3.3€ in 2016) for each pufferfish specimen? If yes, how many individual can you fish a year? In addition, to estimate the total mean value of the damage related to pufferfish in Turkey, the small scale fishers' numbers of sampling areas (Figure 1) were obtained from TUIK data (TUIK, 2018).

In this study a total of 5 pufferfish species were reported by fishers. For all statistical analyses, graphs and tables, we combined all species because some fishers had a difficulty to identify species. However, it is noted here that $66 \%$ of the pufferfish mentioned by fishers (both commercial and recreational) is L. sceleratus.

Statistical analyses were performed with the SPSS software (Version 20). The data were tested for normality and homogeneity of variance using a KolmogorovSmirnov test and Levene's test, respectively. Dependent on the results of aforementioned tests, parametric or non-parametric tests were performed subsequently. To compare the pufferfish by-catch in different types of fishing gear, Kruskal Wallis test was performed. Similarly, Kruskal Wallis test was performed to understand whether the mean body size was different dependent on fishing gear types (1-fishing rod, 2- set net and ongline, 3- trawl and purse seine). Mann-Whitney U-test was used to compare spatial patterns in pufferfish by-catch between south and west coasts.

\section{RESULTS}

The mean number of hooks used per day on longlines was calculated as $725 \pm 400$ and the mean net length per each operation of set nets was 2,893 $\pm 1,661 \mathrm{~m}$. The mean daily operation time per trawl and purse seine was estimated as $15 \pm 2$ and $13 \pm 3 \mathrm{hrs}$ respectively. $93 \%$ of the commercial fishers interviewed spent 100 to 300 working days at sea a year and the mean value of annual working day was calculated as $161 \pm 57$. Estimated annual days at sea of interviewed recreational fishers varied between 5 and 300 days, with $32 \%$ fishing for 100 to 300 days a year and the mean was $80 \pm 69$ days a year.

Respondents identified a total of 5 pufferfish species. These species were Lagocephalus sceleratus, Lagocephalus suezensis, Lagocephalus guentheri, Sphoeroides pachygaster and Torquigener flavimaculosus. Just 2 pufferfish species were identified on the west coast; $L$. sceleratus and L. guentheri. However, all 5 were reported from the south coast. Interviews suggested that the most commonly caught pufferfish species was $L$. sceleratus on both west coast (98\%) and south coast (46\%).

There was no statistically significant difference in the estimated by-catch amounts (year 2016) between types of fishing gears ( $P=0.165$, Chi-square $=6.49$, df $=4)$. The highest pufferfish by-catch was recorded in purse seines and trawls around the south coasts (Table 2). However, there are significant differences in Mediterranean (south) and Aegean (west) coasts in all different fishing gears within the commercial fisheries (Table 2). Similarly, there was a significant spatial difference in by-catch amounts of recreational fisheries between coasts (Table 2). For both commercial and recreational fisheries, the estimated pufferfish by-catch was higher on the south coast than the west coast. When seasonal differences in the by-catch were considered, both recreational and small scale commercial fishers indicated that the highest pufferfish by-catch occurred in summer (Figure 2).

Table 2. Mean catch amount (boat/year) \pm SD (all species; Lagocephalus sceleratus, Lagocephalus suezensis, Lagocephalus guentheri, Sphoeroides pachygaster and Torquigener flavimaculosus) in different fishing gears

\begin{tabular}{lcccccc}
\hline Fishing Gear & \multicolumn{2}{c}{ Sample Size $(\mathbf{n})$} & \multicolumn{2}{c}{ Mean Catch Amount (boat/year) } & \multicolumn{2}{c}{ Mann Whitney U-test } \\
& West C. $(\mathrm{n})$ & South C. $(\mathrm{n})$ & South C. & West C. & 6 Value & $P$ \\
\hline Purse seine & 10 & 11 & $946 \pm 1128$ & $6 \pm 5$ & 66.000 & $<0.001$ \\
Trawl & 36 & 25 & $619 \pm 1356$ & $4 \pm 5$ & 32.000 & $<0.001$ \\
Set net & 34 & 47 & $360 \pm 462$ & $30 \pm 111$ & 86.500 & $<0.001$ \\
Longline & 28 & 45 & $276 \pm 261$ & $4 \pm 9$ & 11.500 & $<0.001$ \\
Fishing rod & 138 & 85 & $252 \pm 518$ & $3 \pm 7$ & 484.000 & $<0.001$ \\
\hline
\end{tabular}

*Purse seine, trawl, set net, and longline are the commercial fishing gears, whilst fishing rod represents the recreational fisheries in this study. South coast includes the cities of Antalya, Mersin, Adana and Hatay while west coast includes the cities of İzmir, Aydın, and Muğla. 


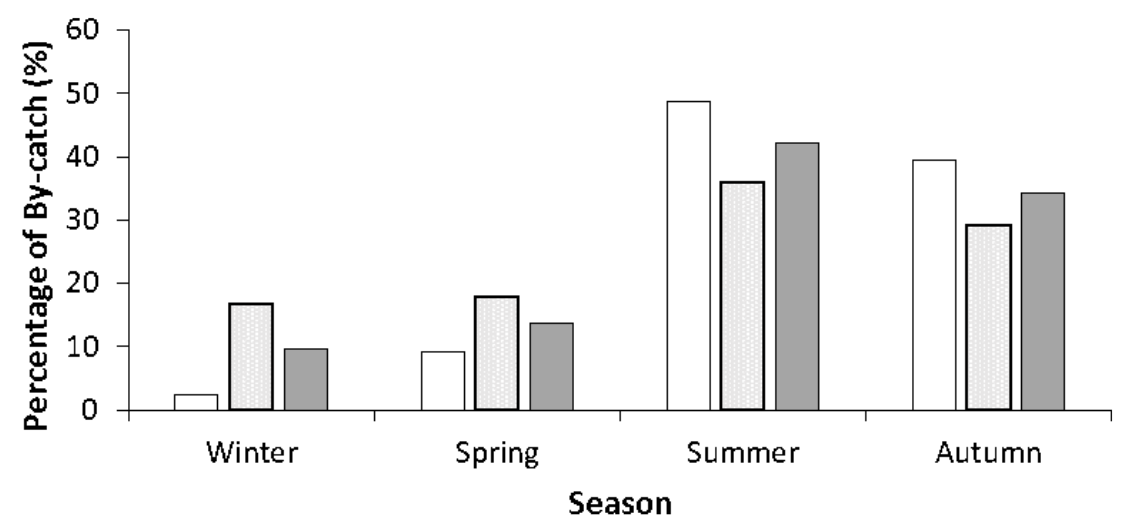

$\square$ Recreational Fisheries $\quad \square$ Small Scale Fisheries $\quad \square$ Recreational and Small Scale Fisheries

Figure 2. The highest pufferfish by-catch in different seasons for recreational and commercial fisheries

Reported pufferfish body size in by-catch varied between 5 to $85 \mathrm{~cm}$ and the common size class was determined as $11-20 \mathrm{~cm}$. The mean body length of pufferfish was calculated as $26 \pm 13 \mathrm{~cm}$ based on the fishers' declaration. The results show that anglers,

A)

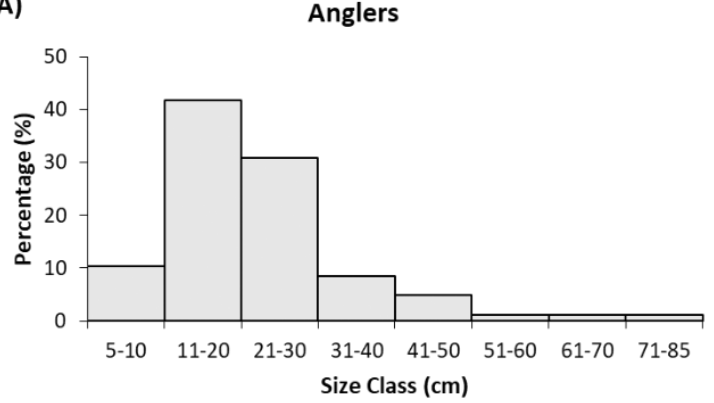

C)

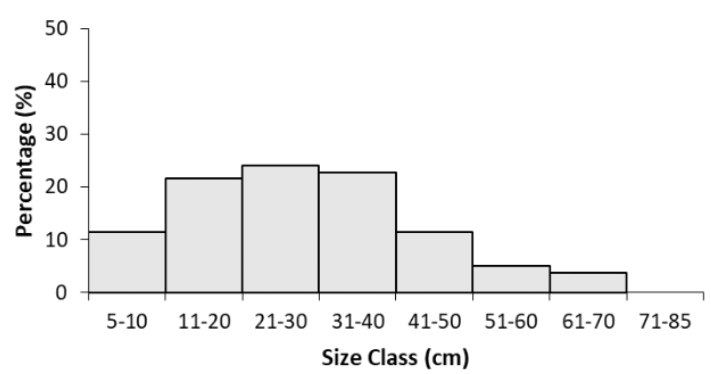

longliners and set netters caught smaller pufferfish in comparison with trawlers and purse seiners (Figure 3). There was a statistically significant difference in body size of pufferfish caught in different fishing gears $(P<0.001$, Chi-square $=21.76, \mathrm{df}=2)$.

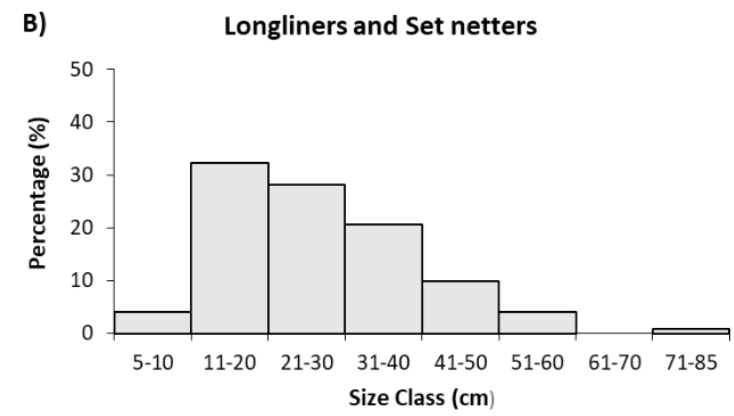

D) All Fishers

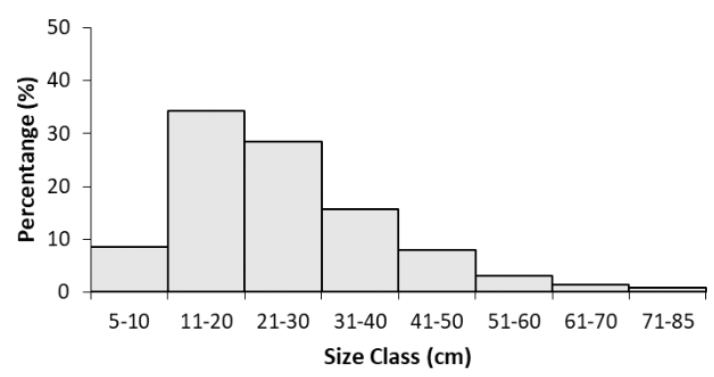

Figure 3. Percentage (\%) of body size estimations of pufferfish species caught by A) anglers, B) longliners and set netters, C) trawlers and purse seiners, D) all fishers 
Pufferfish species were reported from depths of $2 \mathrm{~m}$ to $115 \mathrm{~m}$. Fishers reported that pufferfish species inhabit various habitats including sand, mud, rock, mixed stone, gravel and seagrass meadows. However, they were not able to identify the most preferred habitat of pufferfish.

On the south coast, $57 \%$ of commercial fishers declared that pufferfish were very negatively affecting their fishing activity, whereas on the west coast only $9 \%$ of commercial fishers were very negatively influenced. In particular, longliners and set netters were the most impacted fishers by pufferfish(Table 3).Additionally, all longliners and $70 \%$ of set netters on the south coast stated that pufferfish in their fishing gears impacted the catch productivity, whilst $48 \%$ of longliners and $22 \%$ of set netters on the west coast declared that their catch productivity was impacted by pufferfish (Figure $4 a, 4 b)$. Similar ratios related to the catch composition were found in south and west coasts (Figure 5a, 5b).

Table 3. Fishers' declaration on pufferfish impacts

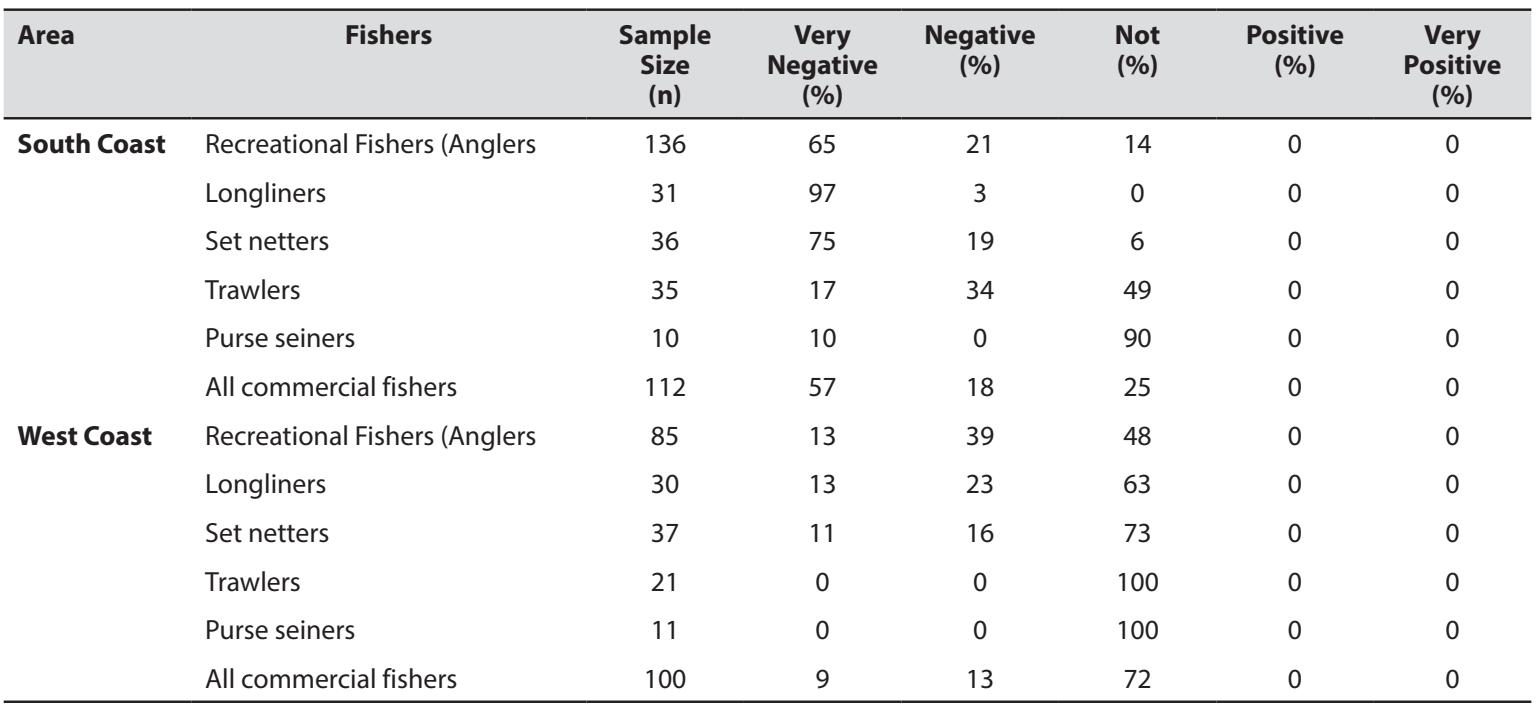

A)

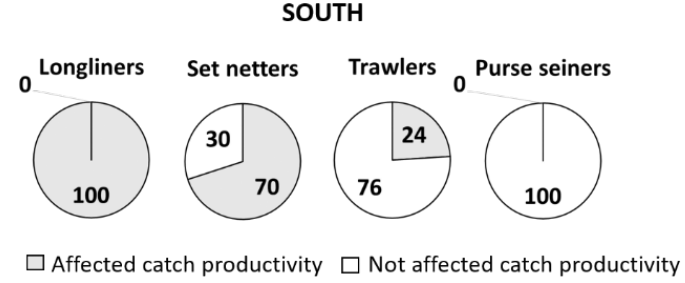

B)

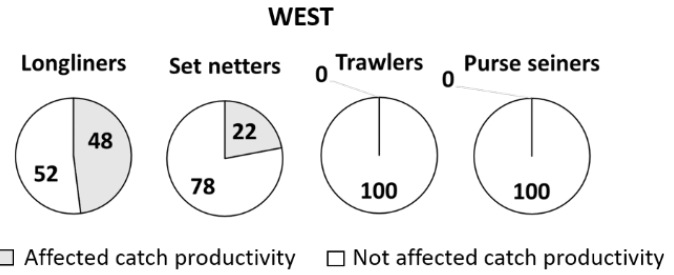

Figure 4. Affected and unaffected catch productivity (\%) for different fishers: A) South Coast, B) West Coast

A)

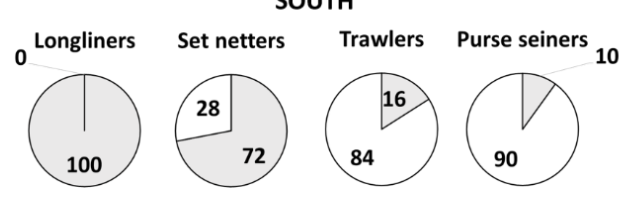

$\square$ Affected catch composition $\square$ Not affected catch composition
B)

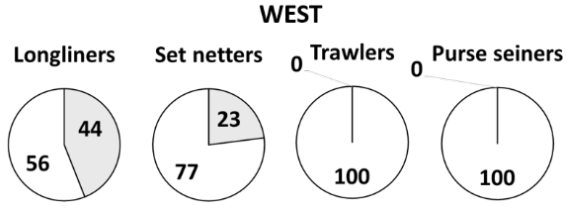

$\square$ Affected catch composition $\square$ Not affected catch composition

Figure 5. Affected and unaffected catch composition (\%) for different fishers: A) South Coast, B) West Coast 
On the south coast, $94 \%$ and $90 \%$ of small scale commercial fishers (longliners and set netters) claimed that pufferfish species damage their fishing gears and fish entangled to these fishing gears, respectively. On the other hand, on the west coast, $30 \%$ and $26 \%$ of commercial fishers claimed that pufferfish species damage their fishing gears and fish entangled to these fishing gears, respectively. For the small scale fisheries, the average loss originated by pufferfish in 2016 for longliners was 2,929.00 TL/vessel (approx. 888 Euro) and for set netters was 3,352.90 TL/vessel (approx. 1,016 Euro). The average loss originated by pufferfish in 2016 in both set net and longline (alternately) was 3,070.60 TL/vessel (approx. 931 Euro). Estimates provided in this study were $113 \%$ and $20 \%$ higher than the reported losses in 2011-2012 and 2013-2014 respectively (Table 4).

Table 4. Annual monetary loss (TL) in fishing gear

\begin{tabular}{|c|c|c|c|}
\hline \multirow{3}{*}{ Gear Type } & \multirow{2}{*}{\multicolumn{3}{|c|}{$\begin{array}{l}\text { Annual monetary loss (TL) } \\
\qquad \text { Mean } \pm \text { SD }\end{array}$}} \\
\hline & & & \\
\hline & $\begin{array}{c}\text { Ünal et al, } 2015 \\
2011-2012 \\
\text { Value }\end{array}$ & $\begin{array}{c}\text { Ünal and Göncüoğlu- } \\
\text { Bodur, } 2017 \\
2013-2014 \\
\text { Value }\end{array}$ & $\begin{array}{c}\text { Present Study } \\
2016 \\
\text { Value }\end{array}$ \\
\hline Longline & $942,4 \pm 1,007.7$ & $2,336.1 \pm 2,087.9$ & $2,929.4 \pm 2,026.0$ \\
\hline Set net & $1,346.9 \pm 1,415.0$ & $2,820.6 \pm 3,393.4$ & $3,352.9 \pm 4,311.8$ \\
\hline Longline and set net (alternately) & $1,440.6 \pm 900,7$ & $2,559.6 \pm 2,781$ & $3,070.6 \pm 2,949.4$ \\
\hline
\end{tabular}

Table 5 shows the annual monetary loss related to the damaged target fish. The small scale fishers interviewed of 59\% reported that monetary loses due to pufferfish by-catch and the study area includes 7 cities and 5,373 fishing boats which include set nets

and longlines. It was estimated that a total of 3,170 fishers in the sampling areas might have monetary loss. Thus, the total mean value of the damage related to pufferfish was calculated at 14,825,225 TL $(\approx 4,507,644$ EUR) per year.

Table 5. Annual monetary loss (TL) in damaged target catch

\begin{tabular}{lccc}
\hline Gear Type & \multicolumn{3}{c}{ Annual monetary loss (TL) } \\
& $\begin{array}{c}\text { Mean } \pm \text { SD } \\
\text { Ünal et al, 2015 } \\
\mathbf{2 0 1 1 - 2 0 1 2} \\
\text { Value }\end{array}$ & $\begin{array}{c}\text { Ünal and Göncüoğlu- } \\
\text { Bodur, 2017 } \\
\mathbf{2 0 1 3 - 2 0 1 4} \\
\text { Value }\end{array}$ & $\begin{array}{c}\text { Present Study } \\
\mathbf{2 0 1 6} \\
\text { Value }\end{array}$ \\
\hline Longline & NA & NA & $2,460.0 \pm 1,742.3$ \\
Set net & NA & NA & $3,410.0 \pm 4,431.1$ \\
Longline and set net (alternately) & NA & NA & $2,776.7 \pm 2,907.5$ \\
\hline
\end{tabular}

$76 \%$ of the small scale fishers who fish on the south coast and $22 \%$ of the small scale fishers fish on the west coast indicated that they would be able to catch pufferfish if 5 TL was paid for each pufferfish specimen. These fishers predicted that if such an application started, they would be able to catch between 300 and 3,000 pufferfish/year.

When pufferfish toxicity awareness was considered commercial fishers had more information than the recreational fishers. According to the survey's results, $10 \%$ of recreational fishers and $7 \%$ of commercial fishers did not know that pufferfish are poisonous and are dangerous for human health. 14\% of recreational fishers and $21 \%$ of commercial fishers declared that they had consumed pufferfish at least one time. Only one commercial fisher stated that he had been poisoned as a result of pufferfish consumption.

In the case of pufferfish by-catch, 31\% of commercial fishers returned pufferfish to the sea alive, whereas $67 \%$ of fishers killed them first and then returned them to the sea. Regarding the recreational fishery, $14 \%$ of fishers returned pufferfish to the sea alive, whereas $79 \%$ of fishers killed and returned them to the sea. Moreover, 3 fishers stated that they consumed them, whilst 8 fishers gave pufferfish to other people. 


\section{DISCUSSION}

In the present study 2 pufferfish species ( $L$. sceleratus, $L$. guentheri) were reported by fishers on the Aegean (west) coast, whilst 5 species were found on the Mediterranean (south) coast. Similarly, Irmak (2012) reported that the abundance of L. sceleratus, L. guentheri and L. suezensis decreased from south to north along the Turkish Coasts of Mediterranean Sea and Aegean Sea. Irmak (2012) also noticed that $T$. flavimaculosus and T. spinosissumus were rarely reported in the Mediterranean Sea. This may be related to the temperature tolerance of pufferfish, which generally distribute warm waters (Irmak, 2012). The mean annual water temperature of the Mediterranean Sea is warmer than the Aegean Sea (TUIK, 2013). In the current study the most commonly reported pufferfish species was Lagocephalus sceleratus in all fishing gears. Coro et al. (2018) evaluated the geographical distribution of $L$. scelaratus in the Mediterranean Basin and reported that the highest abundance of $L$. scelaratus was found in the Eastern Mediterranean. It was estimated that L. scelaratus currently represents $4 \%$ of the weight of the total artisanal catches (Nader et al., 2012; Coro et al., 2018). On the other hand, in Cyprus, as of 2012, the contribution of this species increased to about $50 \%$ of total catches by weight (Ulman et al., 2015).

Little is known regarding the by-catch amounts of pufferfish. Previous studies have estimated the catch per unit effort (CPUE) of L. sceleratus in trawl hauls from Mediterranean coasts (Gücü, 2012; Başusta et al., 2013; Yemişken et al., 2014; Bilecenoğlu, 2016; Özbek et al., 2017), the Aegean coasts (Bilecenoğlu, 2016). The present study indicates that the pufferfish bycatch was highest in purse seine on the south coast with the highest by-catch on the west coast reported in the set net. Interestingly, Ünal et al. (2015) reported that fishers believe the most suitable fishing gear to extirpate pufferfish is purse seine. By-catch amounts of pufferfish significantly different between fishing areas. For small scale, industrial and recreational fisheries the higher by-catch amounts were recorded on the south coast than the west coast. This is related to abundance of pufferfish in these two different regions. Coro et al. (2018) compared the geographical areas in the Mediterranean basin in terms of the geographical reachability for $L$. sceleratus. According to Coro et al. (2018), the geographical reachability distribution predicts medium-to-high probability of occurrence (0.4-0.6) in the Aegean Sea, whilst it predicts the highest probability $(>0.8)$ on the South coast of Turkey.

Moreover, the present study demonstrates the highest by-catch occurred in recreational and small scale fisheries (longlines and set nets) in summer months. This may be related to the metabolism of pufferfish, which are less active and exhibit limited feeding activity when water temperatures decrease (Kalogirou, 2013).

The present study highlights that LEK is a valuable resource from which to estimate size distribution. The mean length of pufferfish was $26 \pm 13 \mathrm{~cm}$ in the present study. From calliper measurements, Aydın (2011) determined the mean length as $27.3 \pm 12.02$ $\mathrm{cm}$ for males and $28.8 \pm 13.35 \mathrm{~cm}$ for females of $L$. sceleratus collected around the Antalya Bay. Trawlers and purse seiners in the present study caught larger fish in comparison with the small scale and recreational fishers. The latter two groups generally fish in shallow waters, while purse seiners and trawlers fish in deeper areas. Hence, the body size distribution of pufferfish may be influenced by depth. Alternatively, older individuals may notice passive fishing gears and actively avoid them, whereas they may not escape from mobile fishing gears such as purse seine and trawls.

Previous reports suggest that $L$. sceleratus is commonly found in shallow and intermediate waters ( 0 to $50 \mathrm{~m}$ ). They live in various habitats including sandy, rocky substrates and seagrass meadows (Rousou et al., 2014). Özbek et al. (2017) performed trawl operations at six depth levels $(25,50,75,100,150,200 \mathrm{~m})$ around the Antalya Bay, and reported the highest abundance of L. sceleratus at $25 \mathrm{~m}$, with non-reported at $200 \mathrm{~m}$. From LEK it is suggested that pufferfish inhabit numerous substrates including sand, mud, rock, mixed stone, gravel and seagrass meadows and they were present at the depths between $2 \mathrm{~m}$ to $115 \mathrm{~m}$.

The present study suggests that commercial fishers of the south coasts of Turkey are more affected in comparison to the fishers of the west coasts. In particular, set netters and longliners have economical loss due to both damaged fishing gears and smashed target catch due to pufferfish. Our study emphasizes that the estimated total annual monetary loss has increased markedly compare to Ünal et al. (2015) and reached almost the same value estimated for 20132014 by Ünal and Göncüoğlu-Bodur (2017). For the small scale fisheries, our study estimates the average loss originated by pufferfish in 2016 in longline was 2,929.0 TL/vessel (approx. 888 Euro) and in set net was 3,352.9 TL/vessel (approx. 1,016 Euro). However, results signified these species have not economically influenced the small scale fishery around the western coasts yet.

The pufferfish species are carnivorous and generally feed on crustaceans (shrimp, crab), mollusc (squids, octopus) and fish (Rousou et al., 2014). Pufferfish should also be considered a problem due to their damage to target species of the commercial fisheries. Our results show that for the small scale fisheries, the average loss originating from pufferfish to the target 
specimens on longlines was 2,460.0 TL/vessel (approx. 746 Euro) in 2016 and on set net was 3,410.0TL/vessel (approx. 1,033 Euro).

Many fishers declared that the populations of pufferfish and other Lessepsians in the Mediterranean Sea have increased markedly for last several years (Tuset et al., 2012; Mavruk et al., 2017). This might be related to decreases in the stocks of native species (particularly predators), because many native species are influenced by overfishing and illegal fisheries (Irmak and Engin, 2015; Engin et al., 2016). When native species are overexploited, invasive species may fill their vacant niche. Pufferfish exhibit fast growth, early reproduction, and high adaptability. There is no fishing pressure, and an absence of natural predators or competitors (Michailidis, 2010; Özbek et al., 2017). Consequently, pufferfish populations are increasing in the Eastern Mediterranean.

These species are consumed by humans in some countries such as Japan (Cohen et al., 2009). However, $L$. sceleratus from the wild (marine capture) is not permitted for human consumption even in Japan (Arakawa et al., 2010; Nader et al., 2012). Therefore, in Japan, L. sceleratus is produced by aquaculture sector (Venmathi Maran et al., 2011). The present study suggests that $76 \%$ of small scale fishers from the Mediterranean region and $22 \%$ of small scale fishers from the Aegean region would target fish pufferfish, if the government regulations allowed it and there was a market value. This may be an effective method to overcome the pufferfish problem in Turkish small scale fishery. The landing statistics of $L$. sceleratus was only available from Cyprus in the Mediterranean Sea where the average annual landing of this species was reported as 31.5 tonnes for the period of 2010-2013 (Özbek et al., 2017).

Consumption of these species can result in human fatalities (Beköz et al., 2013), and this study highlights that Turkish fishers do not have enough information about the poisonous status of pufferfish. The consumption rate is higher in commercial fishers than

\section{REFERENCES}

Acar, C., Ishizaki, S. \& Nagashima, Y. (2017). Toxicity of the lessepsian pufferfish Lagocephalus sceleratus from eastren Mediterranean coast of Turkey and species identification by rapid PCR amplification. European Food Research Technology, 243, 49-57. DOI: 10.1007/s00217-016-2721-1

Akyol, O., Ünal V., Ceyhan T. \& Bilecenoğlu, M. (2005). First Record of the Silverside Blaasop, Lagocephalus sceleratus (Gmelin, 1789), in the Mediterranean Sea. Journal of Fish Biology, 66, 1183-1186. DOI: 10.1111/j.0022-1112.2005.00667.x

Akyol, O. \& Ünal, V. (2017). Long journey of Lagocephalus sceleratus (Gmelin, 1789) throughout the Mediterranean Sea. Natural and recreational fishers. Some fishers also give pufferfish to others for consumption. Fisheries legislation should contain more information about these poisonous species and their impacts on human health. Workshops for fishers may be beneficial.

\section{CONCLUSION}

The Common Fishery Policy (CFP) of the European Commission aims to increase the data collection of discard, by-catch and target catch (Öndes et al., 2017a), which is important for ecosystem based fisheries management. However, neither commercial nor the recreational fishers record target catch or by-catch data properly in Turkey. The present study contributes some way to filling the gap in knowledge of the bycatch of pufferfish by providing novel findings related to seasonal by-catch estimations in the small scale and recreational fishery. Another notable contribution of the study is to emphasize the increasing monetary loss caused by pufferfish by years. The annual monetary loss estimated in this study is about 4,507,644 Euro for 2016. This is higher than the losses reported for 2011-2012 (Ünal et al., 2015). The dramatic increase in monetary losses caused by pufferfish should influence future policy decisions.

In conclusion, considering the overall findings of the present study, it is suggested that fisheries management authorities initiate a detailed data collection system for not only target species but also by-catch species particularly those that create considerable socioeconomic problems for fishers, marine ecosystem and public health. The magnitude of the problem must be quantified before practical management measures can be formulated and instigated mitigate the economic impacts or solve the problem.

\section{ACKNOWLEDGMENTS}

We would like to thank all of the commercial and recreational fishers who participated in the questionnaire survey. We are very grateful to Dr. Laura Bush (United Kingdom) and Mrs. Karolina Krzesniak (İzmir Katip Çelebi University) for the language editing.

Engineering Sciences, 2, 41-47. DOI: 10.28978/nesciences.369534

Aksiray, F. (1987). Turkish Marine Fish Species and Their Identification Keys ( $2^{\text {nd }}$ edition). Publication of University of İstanbul, Turkey, 811 pp. (In Turkish).

Arakawa, O., Hwang, D.-F., Taniyama, S., \& Takatani, T. (2010). Toxins of pufferfish that cause human intoxications. Coastal Environmental and Ecosystem Issues of the East China Sea, 227-244.

Avşar, D. \& Cicek, E. (1999). A New Species Record For The Central And Eastern Mediterranean; Sphoeroides cutaneus (Günther, 1870) (Pisces: Tetraodontidae). Oebalia, 25, 17-21.

Aydın, M. (2011). Growth, reproduction and diet of Pufferfish (Lagocephalus sceleratus, Gmelin, 1789) from Turkey's 
Mediterranean sea coast. Turkish Journal of Fisheries and Aquatic Sciences, 11, 569-576. DOI: 10.4194/trjfas.2011.0318

Azzurro, E., Moschella, P. \& Maynou, F. (2011). Tracking signals of change in Mediterranean fish diversity based on local ecological knowledge. PLOS ONE, 6:e24885. DOI: 10.1371/journal. pone.0024885

Başusta, A., Başusta, N. \& Özer, E.I. (2013). Length-weight relationship of two puffer fishes, Lagocephalus sceleratus and Lagocephalus spadiceus, from Iskenderun Bay, northeastern Mediterranean, Turkey. Pakistan Journal of Zoology, 45(4), 1047-1051.

Beköz, A.B., Beköz, S., Yılmaz, E., Tüzün, S. \& Beköz, Ü. (2013). Consequences of the increasing prevalence of the poisonous Lagocephalus sceleratus in southern Turkey. Emergency Medicine Journal, emermed-2011. DOI: 10.1136/emermed-2011-200407

Bilecenoğlu, M. (2005). Observation on the burrowing behaviour of the Dwarf Blaasop, Torquigener flavimaculosus (Osteichthyes: Tetraodontidae) along the coast of Fethiye, Turkey. Zoology in the Middle East, 35, 29-34. DOI: 10.1080/09397140.2005.10638100

Bilecenoğlu, M., Kaya, M., Cihangir, B. \& Çiçek, E. (2014). An updated checklist of the marine fishes of Turkey. Turk. J. Zool., 38, 901-929. DOI: 10.3906/zoo-1405-60

Bilecenoğlu, M. (2016). Demersal Lessepsian fish assemblage structure in the northern Levant and Aegean Seas. Journal of Black Sea and Mediterranean Environment, 22(1), 46-59.

Briceño, F, Linnane, A.J., Gardner, G., Quiroz, J.C. \& Pecl, G.T. (2015). Predation risk within fishing gear and its implications for Australian southern rock lobster fisheries. PLOS ONE, 10(10):e0139816. DOI:10.1371/journal.pone.0139816

Chamandi, S.C., Kallab, K., Mattar, H. \& Nader, E. (2009). Human Poisoning after Ingestion of Puffer Fish Caught from Mediterranean Sea. Case Report - USEK Medical School Lebanon.

Cohen, N.J., Deeds J.R., Wong, E.S., Hanner, R.H., Yancy, H.F., White, K.D., Thompson, T.M., Wahl, M., Pham, T.D., Guichard, F.M., Huh, I. Austin, C., Dizikes, G. \& Gerber, S.I. (2009). Public health response to puffer fish (Tetrodotoxin) poisoning from mislabeled product. Journal of Food Protection. 72(4), 810-817. DOI: 10.4315/0362028X-72.4.810

Coro, G., Vilas, L.G., Magliozzi, C., Ellenbroek, A., Scarponi, P. \& Pagano, P. (2018). Forecasting the ongoing invasion of Lagocephalus sceleratus in the Mediterranean Sea. Ecological Modelling, 371 37-49. DOI: 10.1016/j.ecolmodel.2018.01.007

Çek-Yalnız, Ş., Turan, F. \& Doğdu, A.S. (2017). Maturation and Gonad Development of Yellowspotted Puffer Torquigener flavimaculosus (Osteichthyes: Tetraodontidae) from Iskenderun Bay, Northeastern Mediterranean. Natural and Engineering Sciences, 2, 1-11. DOI: 10.28978/nesciences.368991

Çiçek, E. \& Avsar, D. (2015). Lessepsian fishes at the bottom traw fishery in the Babadillimani bigth, northeastern Mediterranean coast of Turkey. 67(4), 43-50.

Dawe, J. \& Schneider, D. (2014). Consilient knowledge in fisheries: a case study of three species of wolffish (Anarhichadidae) listed under the Canadian Species at Risk Act. Ecology and Society, 19(3), 26. DOI: 10.5751/ES-06674-190326

Deidun, A., Fenech-Farrugia, A., Castriota, L., Falautano, M., Azzurro, E. \& Andaloro, F. (2015). First record of the silver-cheeked toadfish Lagocephalus sceleratus (Gmelin, 1789) from Malta. Biolnvasions Records, 4(2), 139-142. DOI: 10.3391/bir.2015.4.2.11

Engin, S., Irmak, E. \& Seyhan, D. (2016). New record of the thermophilic Cephalopholis taeniops (Osteichthyes: Serranidae) in the Aegean Sea. Zoology in the Middle East, 62(2), 184-186. DOI: 10.1080/09397140.2016.1173908

EP. (2015) The landing obligation and its implications on the control of fisheries. European Parliament Report, 122 pp.

Eryilmaz, L., Özulu, M. \& Meriç, N. (2003). The Smooth Pufferfish, Sphoeroides pachygaster (Müller \& Troschel, 1848) (Teleostei: Tetraodontidae), new to the Northern Aegean Sea. Zooloy in the Middle East, 28, 125-126. DOI: 10.1080/09397140.2003.10637962

Gücü, A.C. (2012). Impact of depth and season on the demersal trawl discard. Turkish Journal of Fisheries and Aquatic Sciences, 12(4), 817-830. DOI: 10.4194/1303-2712-v12 4 _10.

Hastings, P, Walker, H.J. \& Galland, G. (2014). Fishes: a guide to their diversity. University of California Press, Oakland, $311 \mathrm{pp}$.

Irmak, E. (2012). Türkiye kıyılarındaki Lessepsiyen balon balıklarının dağılımı ve beslenme özellikleri. [Lessepsian pufferfi shes on the Turkish coasts and their feeding properties.] PhD Thesis. Çanakkale Onsekiz Mart University. [In Turkish.]

Irmak, E. \& Engin, S. (2015). A newly established population of the Indian Ocean Twospot Cardinalfish, Cheilodipterus novemstriatus (Rüppell, 1838), in the Northern Levantine Sea (Osteichthyes: Apogonidae). Zoology in the Middle East, 61(2), 186-188. DOI: 10.1080/09397140.2015.1035009

Kalogirou, S. (2013). Ecological characteristics of the invasive pufferfish Lagocephalus sceleratus (Gmelin, 1789) in Rhodes, Eastern Mediterranean Sea. A case study. Mediterranean Marine Science, 14, 251-260. DOI: 10.12681/mms.364

Kaiser, M.J., Attrill, M.J., Jennings, S., Thomas, D.N., Barnes, D.K.A., Brierley, A.S., Hiddink, J.G., Kaartokallio, H., Polunin, N.V.C. \& Raffaelli, D.G. (2011). Marine Ecology: Processes, Systems, and Impacts, second edition. Oxford University Press, Oxford.

Katikou, P., Georgantelis, D., Sinouris, N., Ptesi, A. \& Fotaras, T. (2009). First Report on Toxicity Assessment of the Lessepsian Migrant Puffer Fish Lagocephalus sceleratus (Gmelin, 1789) From European Waters (Agean Sea, Greece). Toxicon, 54, 50-55. DOI: 10.1016/j.toxicon.2009.03.012

Kelleher, K. (2005). Discards in the world's marine fisheries: an update. Food and Agriculture Organization of the United Nations (FAO) Fisheries Technical Paper, no. 470. Rome: FAO.

Kosker, A. R., Özogul, F., Durmus, M., Ucar, Y., Ayas, D., Regenstein, J.M. \& 
Özogul, Y. (2016). Tetrodotoxin levels in pufferfish (Lagocephalus sceleratus) caught in the Northeastern Mediterranean Sea. Food Chemistry, 210, 332-337. DOI: 10.1016/j.foodchem.2016.04.122

Kosswig, C. (1950). Erythräische Fische im Mittelmeer und an der Grenze der Ägais. Pp. 203-212. In: Von Jordans A., Peus F. (eds.) Syllegomena Biologica. Festschrift zum 80. Geburtstage von Herrn Pastor Dr. Med. H.C. Otto Kleinschmidt, Lutherstadt Wittenberg am 13. Dezember 1950. Geest und Portig K.-G./A. Ziemsen Verlag, Leipzig und Wittenberg, Germany.

Leite, M.C. \& Gasalla, M.A. (2013). A method for assessing fishers' ecological knowledge as a practical tool for ecosystembased fisheries management: seeking consensus in south-eastern Brazil. Fisheries Research, 145, 43-53. DOI: 10.1016/j.fishres.2013.02.013

Macdonald, P., Angus, C.H., Cleasby, I.R., Marshall, C.T. (2014). Fishers' knowledge as an indicator of spatial and temporal trends in abundance of commercial fish species: megrim (Lepidorhombus whiffiagonis) in the northern North Sea. Marine Policy, 45, 228239. DOI: 10.1016/j.marpol.2013.11.001

Mavruk, S., Bengil, F., Yeldan, H., Manasirli, M. \& Avsar, D. (2017) The trend of lessepsian fish populations with an emphasis on temperature variations in Iskenderun Bay, the Northeastern Mediterranean Fisheries Oceanography, 1-13. DOI: 10.1111/ fog. 12215

Michailidis, N. (2010). Study on the lessepsian migrant Lagocephalus sceleratus in Cyprus. In: EastMed, Report of the Sub-Regional Technical meeting on the Lessepsian migration and its impact on Eastern Mediterranean fishery (pp.74-87). Scientific and Institutional Cooperation to Support Responsible Fisheries in the Eastern Mediterranean, GCP/INT/041/EC - GRE - ITA/TD-04, Athens, $138 \mathrm{pp}$.

Nader, M., Indray, S. \& Boustany, L. (2012). The pufferfish Lagocephalus sceleratus (Gmelin, 1789) in the Eastern Mediterranean. FAOEastMed Project, Athens, Greece. GCP/INT/041/EC-GRE-ITA/ TD-10.

Öndes, F., Kaiser, M.J. \& Murray, L.G. (2017a). Fish and invertebrate by-catch in the crab pot fishery. Journal of the Marine Biological Association of the UK, 1-13. DOI: 10.1017/S0025315417001643

Öndes, F, Emerson, J., Kaiser, M.J., Murray, L.G. \& Kennington, K. (2017b). The catch characteristics and population structure of the brown crab (Cancer pagurus) in the Isle of Man. Journal of the Marine Biological Association of the UK, 1-15. DOI: $10.1017 /$ S002531541700184.

Özbek, Ö.E., Çardak, M. \& Kebapçıoğlu, T. (2017). Spatio-temporal patterns of abundance, biomass and length of the silvercheeked toadfish Lagocephalus sceleratus in the Gulf of Antalya, Turkey (Eastern Mediterranean Sea). Turkish Journal of Fisheries and Aquatic Sciences, 17, 725-733.

Por, F.D. (1964). A study of the Levantine and Pontic Harpacticoida (Crustacea, Copepoda). Zoologische Verhandelingen, Leiden, 64, $1-128$.
Posey, D. \& Balick, M. (2006). Human impacts on Amazonia: the role of traditional ecological knowledge in conservation and development. New York: Columbia University Press. DOI:10.7312/pose10588

Rousou, M., Ganias, K., Kletou, D., Loucaides, A. \& Tsinganis, M. (2014). Maturity of the pufferfish Lagocephalus sceleratus in the southeastern Mediterranean Sea. Sexuality and early development in aquatic organisms, 1, 35-44.

Soykan, C.U., Moore, J.E., Zydelis, R., Crowder, L.B., Safina, C. \& Lewison R.L. (2008). Why study by-catch? An introduction to the theme section on fisheries bycatch. Endangered Species Research, 5, 91-102. DOI:10.3354/esr00175

Streftaris, N. \& Zenetos, A. (2006). Alien marine species in the Mediterranean - the 100 'worst invasives' and their impact. Mediterranean Marine Science, 7(1), 87-118. DOI:10.12681/ mms. 180

TUIK, 2013. Türkiye İstatistik Kurumu. Türkiye İstatistik Yıllığı (2013). Erişim: 04.03.2018.

TUIK, 2018. Türkiye İstatistik Kurumu. <biruni.tuik.gov.tr/medas/> Erişim: 22.03.2018.

Turan, C. \& Yaglioglu, D. (2011). First record of the Spiny blaasop Tylerius spinosissimus (Regan, 1908) (Tetraodontidae) from the Turkish coasts. Mediterranean Marine Science, 12(1), 247252. DOI: $10.12681 / \mathrm{mms} .63$

Turan, C., Gürlek, M., Ergüden, D., Uyan A., Karan, S. \& Doğdu, S.A. (2017). Assessing DNA Barcodes for Identification of Pufferfish Species (Tetraodontidae) in Turkish Marine Waters. Natural and Engineering Sciences, 2(3), 55 - 66. DOI: 10.28978/nesciences.369538

Tuset, V.M., Azzurro, E. \& Lombarte, A. (2012). Identification of Lessepsian fish species using the sagittal otolith. Scientia Marina 76(2), 289-299, DOI: 10.3989/scimar.03420.18E

Ulman, A., Çiçek, B.A., Salihoğlu, I., Petrou, A., Patsalidou, M., Pauly, D. \& Zeller, D. (2015). Unifying the catch data of a divided island: Cyprus's marine fisheries catches, 19502010. Environment Development and Sustainability, 17, 801821. DOI: 10.1007/s10668-014-9576-Z

Ünal, V., Göncüoğlu, H., Durgun, D., Tosunoğlu, Z., Deval, C. \& Turan, C. (2015). Silver-Cheeked Toadfish, Lagocephalus sceleratus (Actinopterygii: Tetraodontiformes: Tetraodontidae), Causes A Substantial Economic Losses In The Turkish Mediterranean Coast: A Call For Decision Makers. Acta Ichthyologica et Piscatoria, 45(3), 231-237.DOI: 10.3750/AIP2015.45.3.02

Ünal, V. \& Göncüoğlu-Bodur, H. (2017). The socio-economic impacts of the silver-cheeked toadfish on small-scale fishers: A comparative study from the Turkish coast. Ege Journal of Fisheries and Aquatic Sciences, 34, 119-127. DOI: 10.12714/egejfas.2017.34.2.01

Vella, A., Vella, N., Karakulak, F.S. \& Oray, I. (2017). DNA Barcoding of Tetraodontidae Species from the Mediterranean Sea: Filling Knowledge Gaps for Improved Taxonomic Accuracy. Genetics of Aquatic Organisms, 1, 61-69. DOI: 10.4194/2459-1831-v1_2_05 
Venmathi Maran, B.A., Ohtsuka, S., Takami, I., Okabe, S. \& Boxshall, G.A. (2011). Recent advances in the biology of the parasitic copepod Pseudocaligus fugu (Siphonostomatoida, Caligidae), host specific to pufferfish of the genus Takifugu (Actinopterygii, Tetraodontidae) In: Asakura A, et al., editors. Crustaceana Monographs 15: new frontiers in crustacean biology. Leiden: Brill; pp. 31-45. DOI: 10.1163/ej.9789004174252.i-354.30

Yemişken, E., Dalyan, C. \& Eryılmaz, L. (2014). Catch and discardfish species of trawl fisheries in the Iskenderun Bay (Northeastern Mediterranean) with emphasis on lessepsian and chondricthyan species. Mediterranean Marine Science, 15(2), 380-389. 